\title{
The Difference in Marketed Surplus of Local Varieties Rice Farmers
}

\author{
S Hidayani, D H Darwanto, Irham, Jamhari \\ Faculty of Agriculture Gadjah Mada University, Indonesia \\ sarahhidayani@gmail.com
}

\begin{abstract}
Marketed surplus is needed to find out how many harvests will be sold to the market by farmers after being used for consumption, seeds and harvest and post-harvest activities. Marketed surplus owned by farmers is stored at home, in its own warehouse, in rice mills and in Warehouse Receipts. Therefore, in this study a comparison was made to determine the difference in marketed surplus between farmers who participated in the Warehouse Receipt System and those who did not follow. On this study, marketed surplus of farmers is influenced by the area of land and the number of dependents related to the amount of consumption reserved from the harvest.
\end{abstract}

Keywords: Market Surplus, Farmers, harvest.

\section{INTRODUCTION}

Barito Kuala Regency is an area that produces local varieties of rice in South Kalimantan Indonesia. Most of the people of South Kalimantan, which is the Banjar tribe, like the local rice varieties that are pera and the granules are small and long. These local varieties of rice are planted in swamps with a planting period of up to 8 months. The long planting period causes harvesting only once a year

Storage of grain is carried out by farmers in Barito Kuala regency to anticipate the harvest season that only once a year. Local varieties are resistant to acidic and submerged wetlands. For that reason, farmers store this grain to cover up famine and increase selling prices at that time. The storage of most farmers is still traditional because they mostly store themselves at home. But there are also farmers who store their crops through a warehouse receipt system. Febrian's research results [1] Warehouse Receipt System provided by the government to assist farmers in an effort to increase farmer's income has several benefits, namely non-economic benefits and economic benefits. The non-economic benefits felt by farmers who use the SRG are the benefits of storage, security benefits, quality assurance benefits and marketing benefits. The benefit of storage obtained by respondent farmers is that farmers can save grain if they do not have a large place. The benefit of security is that farmers get insurance for their grain. The 
benefit of quality assurance obtained by respondent farmers is that the farmers' grain gets a certificate of quality over the grain.

The purpose of this study was to find out the marketed surplus of farmers who followed the warehouse receipt system and those who did not. The marketed surplus is that quantity of the produce, which the farmer actually sells in the locality and market, irrespective of his requirements for family consumption, farm needs and other payments. The marketed surplus may be more, less or equal to the marketable surplus depending on various conditions [2]. The marketable surplus increases with the increase in the farm size both in quantity and percentage terms.[3]

\section{METHODS}

This study took place in Barito Kuala District, South Kalimantan Province. The selection of research locations was done purposively with consideration because Barito Kuala Regency was the center of local varieties of rice production and also the only district in South Kalimantan that had Warehouse Receipt

The purpose of this study was to compare marketed surpluses between farmers who followed the Warehouse Receipt System and those who did not. For this reason, the sub-district selection was deliberately determined against the sub-district located in the vicinity of the warehouse receipt location namely Mandastana sub-district, Rantau Badauh, Alalak, Anjir Muara and Tamban

The data used in this study are primary data and secondary data. Primary data was obtained from the results of direct interviews with farmers and marketing institutions involved and also the managers of Warehouse Receipts and related parties. The farmers referred to in this study were rice farmers who applied and did not implement the Warehouse Receipt System. Interviews were conducted using a questionnaire in the form of a questionnaire. Direct observation was carried out in the field. Interviews were conducted with warehouse managers using a list of questions in the form of a questionnaire. Secondary data was obtained through written reports from the mass media, institutions and agencies related to this research such as Ministry of Trade, Central Bureau of Statistics, District Agriculture Service, and others.

To find out the comparison of marketed surpluses between farmers participating in the SRG and farmers who did not join the SRG, they were analyzed using the following formula [4]:

$$
\begin{gathered}
\text { Marketable surplus }=\text { Total production }- \text { Requirement payment }(1) \\
\text { Marketed Surplus }=\text { Marketable Surplus }- \text { consumption, seed (2) }
\end{gathered}
$$

\section{RESULT and DISCUSSION}

Based on the results of interviews with farmers, it can be seen in table 1, that most farmers are small farmers based on the area of land they have. It means, most of them are subsistence farmers, who seek small-scale agriculture especially to fulfill their own household needs. After the needs for their consumption are met, the rest will be sold in stages according to their needs by looking at the selling price of rice. 
Table 1. The number and percentage of respondent farmers based on farm size

\begin{tabular}{cccc}
\hline Farm Size & WRS farmers & Non WRS farmers & $\%$ \\
\hline Marginal (0-1,00 ha) & 0 & 21 & 30 \\
Small (1,00-2,00 ha) & 10 & 22 & 53 \\
Large (2,00 and above) & 5 & 7 & 17 \\
Total/overall & 15 & 50 & 100 \\
\hline
\end{tabular}

Table 2. Number of dependent people according to members of WRS

\begin{tabular}{cccc}
\hline Number of Dependent People & WRS farmers & Non WRS farmers & Overall \\
& & & \\
\hline 1 to 3 & 9 & 28 & 37 \\
4 to 6 & 6 & 22 & 28 \\
Total/overall & 15 & 50 & 65 \\
\hline
\end{tabular}

Most responden farmers have dependents between 1 and 3 people as shown in Table 2 .. Can be said to consist of 1 wife and 2 children. This is because of the existence of a Family Planning program that has been implemented by the government for a long time. The program aims to limit the number of births, with the slogan of two children sufficient. In a marketed surplus the number of family dependents affects the amount of household consumption. With at least members of the family, the amount of the crop to be marketed will be even greater.

While the demand for local varieties of rice is quite high. So that from the farmers themselves there is a habit to store the yield of the panes in the form of dry grain. The place where farmers store their grain is at home, in their own warehouses, in warehouse receipts and in mills. Farmers will sell a portion of their paddy as soon as they are finished harvesting is used to pay for the harvest costs. But the other results will be stored for consumption and seedlings and for sale later. The local community's wisdom to store this grain is due to the condition of the land and local varieties that are resistant to the condition of the land. In addition, local varieties of rice are also resistant to storage and the longer the stored price will be more expensive.

Table 3. Market Surplus accoeding to WRS and Non WRS Farmers

\begin{tabular}{lcccc}
\hline \multicolumn{1}{c}{ Description } & WRS farmers & \% & Non WRS farmers & \% \\
\hline Total Production $(\mathrm{kg})$ & 7949,33 & 100 & 7331,13 & 100 \\
\hline Family consumption $(\mathrm{kg})$ & 372,72 & 4,69 & 402,96 & 5,50 \\
\hline Seed purpose $(\mathrm{kg})$ & 159,02 & 2,00 & 148,76 & 2,03 \\
\hline Requirement payment $(\mathrm{kg})$ & 1196,36 & 15,05 & 1271,39 & 17,34 \\
\hline Marketable surplus $(\mathrm{kg})$ & 6752,97 & 84,95 & 6059,75 & 82,66 \\
\hline Marketed Surplus $(\mathrm{kg})$ & 6221,23 & 78,26 & 5508,03 & 75,13 \\
\hline
\end{tabular}


Based on table 3, it can be seen that there are differences in the number of marketed surpluses between farmers who follow a warehouse receipt system with farmers who do not follow. Marketed surplus of farmers who follow the Warehouse Receipt System is $3.13 \%$ greater than farmers who do not follow the warehouse receipt system. Indeed, the number of differences is not too large, probably due to the number of sample farmers who follow the Warehouse Receipt System which is not much. Total production, family consumption, seed purpose, requirement payment, marketable surplus and marketed surpulus based on milled dry grain. The amount of household consumption is calculated based on the average amount of family consumption for one year. Requirement payment is the amount of crop sold to cover the costs of harvest and post-harvest per farmer's household at one planting season. Seed purpose are also taken from the harvest that are self-seeded by farmers for the next planting season

The difference in marketed surplus can be influenced by the area of land owned by farmers where the warehouse receipt system has an average land area of more than 2 ha. Whereas for farmers who do not follow the warehouse receipt system there are marginal farmers whose land area is less than 2 ha as table 1 is 46 percent.

This is also influenced by the large number of family consumption which is in line with the number of dependents of the farmer family. For farmers who follow the warehouse receipt system the amount of family consumption is smaller than farmers who do not follow the warehouse receipt system as in tables 2 and 3 .

\section{CONCLUSION}

Based on the results and discussion, it can be concluded that there are differences in the number of marketed surpluses between farmers who follow the warehouse receipt system and farmers who do not follow the warehouse receipt system. This is influenced by, among others, the area of land and the amount of family consumption which is influenced by the number of dependents of the farmer's family.

\section{REFERENCES}

[1] A. Febrian, "Analisis Pendapatan Usahatani Padi dengan Memanfaatkan Sistem Resi Gudang studi kasus Gapoktan Jaya Tani Indramayu,” Institut Pertanian Bogor, 2011.

[2] V. Kumar, S. Dwivedi, S. Narain, S. K. Rawat, and B. R. S. Chauhan, "Assesment of Marketable and Marketed Surplus of Rice in Relation to Fam Size," Agro Econ. Int. J., vol. 2, no. 2, 2014.

[3] P. Kumar, "Marketed Surplus of Different Crops Across Farm Size: A Study in Haryana," Ind. Jn. Of. Agri. Econ, vol. 54, no. 4, 1999.

[4] M. D. Newman, "Determinants of Marketed Surplus on Rural Household Toward an Applied Research Agenda From an African Policy Perspective," Michigan State University, 1977. 